\title{
BUS RAPID TRANSIT: AN ENVIRONMENTAL FRIENDLY TRANSPORT SOLUTION FOR ISTANBUL
}

\author{
ELIF CAN CENGIZ \\ Istanbul Technical University, City and Regional Planning, Istanbul, Turkey.
}

\begin{abstract}
According to the United Nations, in 2014, 54\% of the world's population was living in cities, and it is estimated to be $66 \%$ by 2050 . The pressure of urbanization on the urban environment cannot be ignored. Istanbul is one of the most important and biggest cities in the world. It is the biggest city in Turkey in terms of both economy and population. A total of 15 million people are living in Istanbul, that is, $18 \%$ of the total population of Turkey, which creates high-mobility needs. Istanbul has marine, rail and road transportation. In 2005, to improve road transportation, the city officials decided to implement Bus Rapid Transit (BRT) system on one of the city's most important corridors. In 2007, the system started operation with $18.2 \mathrm{~km}$ route length. The aim was to reduce both heavy traffic and negative environmental impacts of road transportation on the corridor. At present, the system carries more than 800,000 passengers/day with $52 \mathrm{~km}$ route length. BRT system in Istanbul is a shining star in the world of BRT because of its high passenger numbers and high commercial speed. This article aims to discuss the positive impacts of BRT system on Istanbul's environment in terms of vehicles eliminated from the general traffic and reduced amount of $\mathrm{CO}_{2}$ due to BRT. As BRT provides rapid transit possibilities, private vehicle users shifted to the new system.
\end{abstract}

Keywords: BRT, $\mathrm{CO}_{2}$ emissions, Istanbul, public transport.

\section{INTRODUCTION}

Istanbul, the largest city in Turkey, lies in Marmara region which is a transition point between Anatolia and Balkan Peninsula. Bosporus naturally divides the city into two parts (Fig. 1).

According to the 2015 demographic data the total population of the city is $14,657,434$ people, surface area is $5,313 \mathrm{~km}^{2}$ and population density is 2,759 persons $/ \mathrm{km}^{2}$ [2].

Istanbul's urban development is mainly determined by its geographic features. It has limited liveable area because of forests, water basins, ecologically and biologically unique areas and rugged topography in the northern side of the city. Istanbul has a linear macroform located along the Marmara Sea coast. Linear development of the city is a result of its two main highways: the state highway (D-100) and the motorway which is a part of TransEuropean Motorway. These two main highways attracted development along their path and reinforced the linear growth of the city from east to west. However, today urban sprawl and development trends are also observed towards the northern protected areas. Furthermore, a third bridge that is currently under construction on the northern tip is likely to increase the development pressure towards north (Fig. 2). 


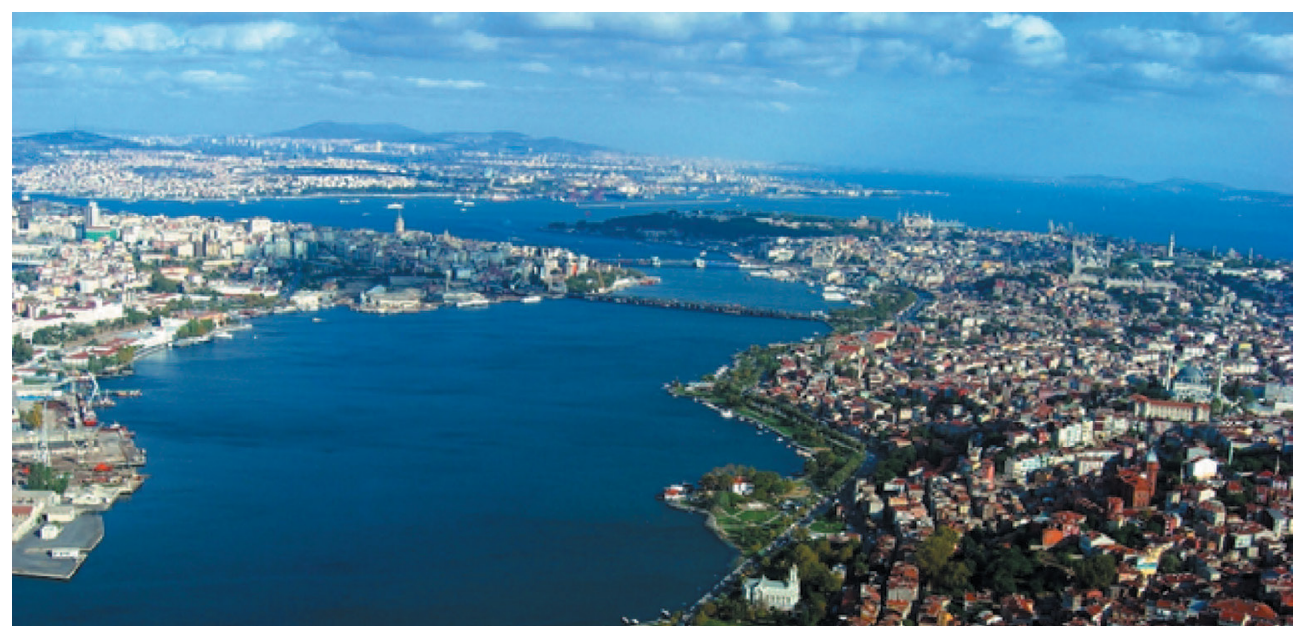

Figure 1: Bosporus divides Istanbul into two parts [1].

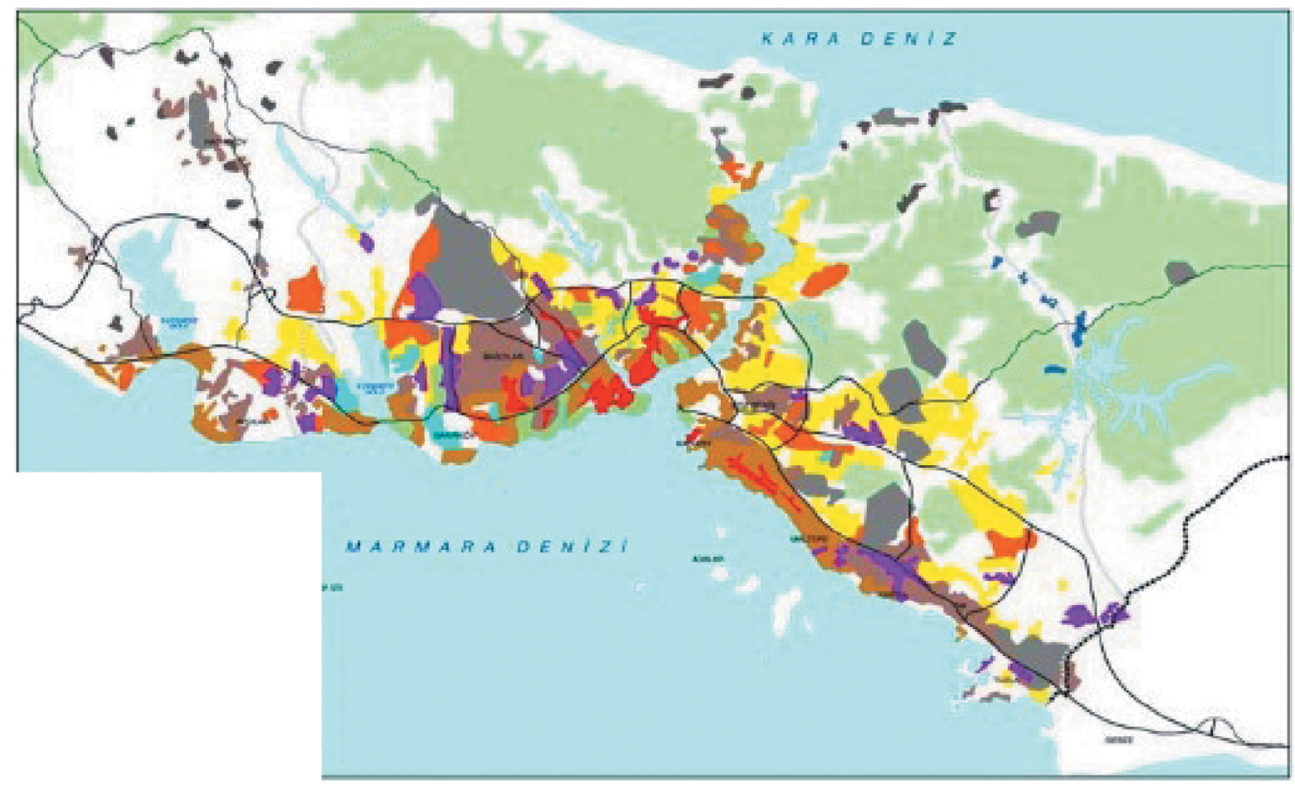

Figure 2: Two main highways of the city and development along them [3].

\section{TRANSPORTATION IN ISTANBUL}

According to the Istanbul Transportation Master Plan [3], half of the trips in Istanbul are made by foot. This is a high ratio indicating the importance of the development of alternatives to the automobile. Furthermore, due to the historical urban pattern, many central areas cannot accommodate increasing volumes of car traffic, leading to unnecessary traffic congestion and creating major traffic problems (Fig. 3).

Istanbul has been investing on its public transportation systems, especially on rail traffic, since the 1980s. However, the coverage of the urban rail systems is rather low; they are constantly expanding, but the progress is slow due to the construction time and the cost involved 


\section{PUBLIC TRANSPORT}

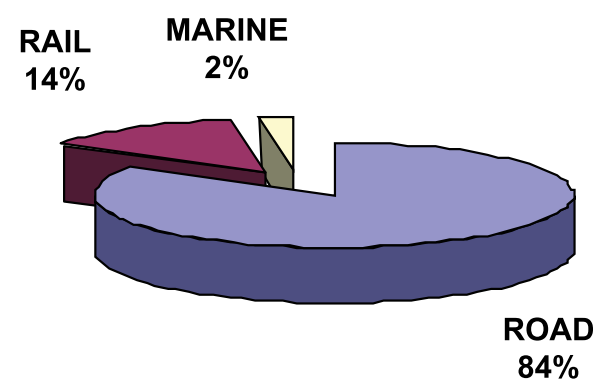

Figure 3: Distribution of public transport modes.

\section{ROAD TRANSPORTATION}

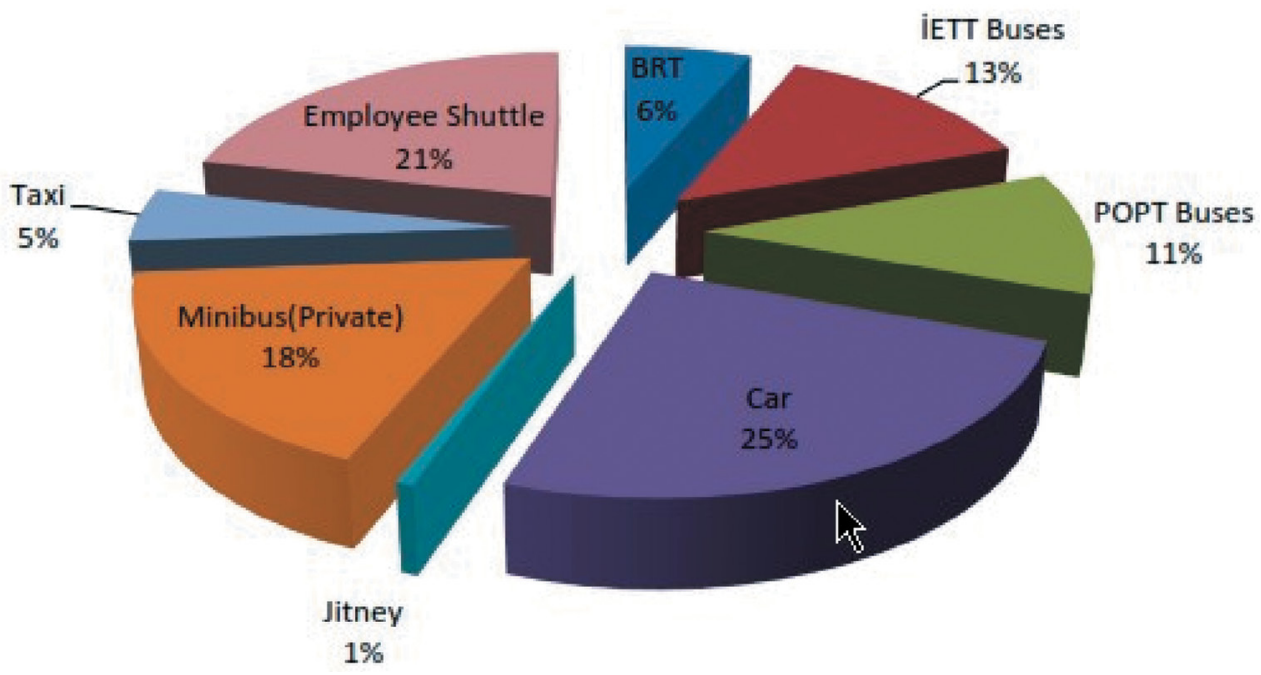

Figure 4: Road transportation by modes.

in these systems. Bosporus has always been an obstacle for an integrated transportation network as Istanbul has one part in Asia and the other in Europe. Each part has its own transportation network. As a result the share of the daily rail transport is relatively low. Two separate rail networks were connected with Marmaray, the rail tunnel crossing Bosporus underwater, just at the end of 2013 (Fig. 4).

Despite having a unique location, the share of marine transport is also low (Fig. 3).

\section{BUS SYSTEMS IN URBAN TRANSPORT}

Grava [4] describes buses as the workhorses of the transit world. There are many cities that offer only bus transit as public transportation and there is no city without bus operations.

According to Black [5] bus transit provides flexibility in operation, since vehicles can operate on any solid street surface, routes can be changed and shifted without any capital cost. 
Buses can easily cope with temporary obstacles that may appear on the streets and bypass the disabled bus in front. However, due to congested roads, the quality of service provided by buses often declines as the duration of the journey increases, while speed, punctuality and reliability decrease.

Designated traffic lanes that are exclusive to public transport is one means of overcoming congestion-related problems, creating an advantage for buses over private vehicles by lessening the effects of traffic congestion.

According to the Federal Transit Administration, the allocation of an exclusive right of way for bus operations can lead to line-haul efficiencies of rail transit while maintaining the distribution flexibility of bus services [6].

\section{BUS RAPID TRANSIT}

As Wright et al. [7] have stated: 'BRT is a high-quality bus based transit system that delivers fast comfortable and cost effective urban mobility through the provision of segregated right-of-way infrastructure, rapid and frequent operations and excellence in marketing and customer service.'

Bus Rapid Transit (BRT) competes with modern rail-based transit system in terms of performance and amenity characteristics with lower implementation and operation costs. Basically, the system combines the quality of rail transit and flexibility of buses (Fig. 5).

\section{BRT IN ISTANBUL}

\subsection{Background and objectives}

The population of Istanbul is increasing rapidly due to intense economic activities and development, thus expanding the urban area. Registered private cars have increased from 707,000 to 2.2 million in the last two decades [2].

Passenger mobility in Istanbul is also very high. According to a 2011 household survey conducted by the Metropolitan Municipality of Istanbul, the number of daily trips is 20.9 million: 10.3 million trips are pedestrian related and the rest are with motor vehicles. Daily trip length per person is also very high, due to its urban development pattern. Since sub-centre development in Istanbul is very weak, the city has expanded from the centre to the periphery rapidly without any sufficient sub-centres with job opportunities being created. This results in long journeys to the city centre for work purposes and for most services and amenities.

Rail investments require high investment and maintenance costs and also longer construction time. In the 2000s many rail investments were started in Istanbul, but the city was in

\begin{tabular}{|c|c|c|}
\hline Major Elements of BRT & System Performance & System Benefits \\
\hline Running Ways & Travel Time Savings & Ridership \\
\hline Stations & Reliability & Transit Supportive Land Development \\
\hline Vehides & Identity and Image & Environmental Quality \\
\hline Fare Collection & Safety and Security & Capital Cost Effectiveness \\
\hline ITS Elements & Capacity & Operating Efficiency \\
\hline
\end{tabular}

Figure 5: BRT elements. 
need of a quick and lower cost solution to meet its transportation demand on the main arterial roads of the city.

The corridor that BRT is implemented is one of the most important highways, the D-100 highway, along which the city had grown. On the Asian side, the highway passes through some green and open areas; however, on the European side, the corridor and surrounding areas are densely populated.

One of the main objectives of this corridor was to attract especially private car users to make use of public transport by providing fast, reliable and comfortable service. In order to decrease private car usage and attract people to public transportation it was aimed to increase the capacity and quality of service on this corridor (Fig. 6).

Istanbul also suffers from high air pollution caused by transportation activities. While planning and implementing BRT in Istanbul to reduce greenhouse gas emissions was another objective, it was intended to decrease the number of private cars in the corridor and also reduce the number of low-capacity old public transportation vehicles that pollute the environment the most, such as low-technology conventional buses and particularly minibuses (Fig. 7).

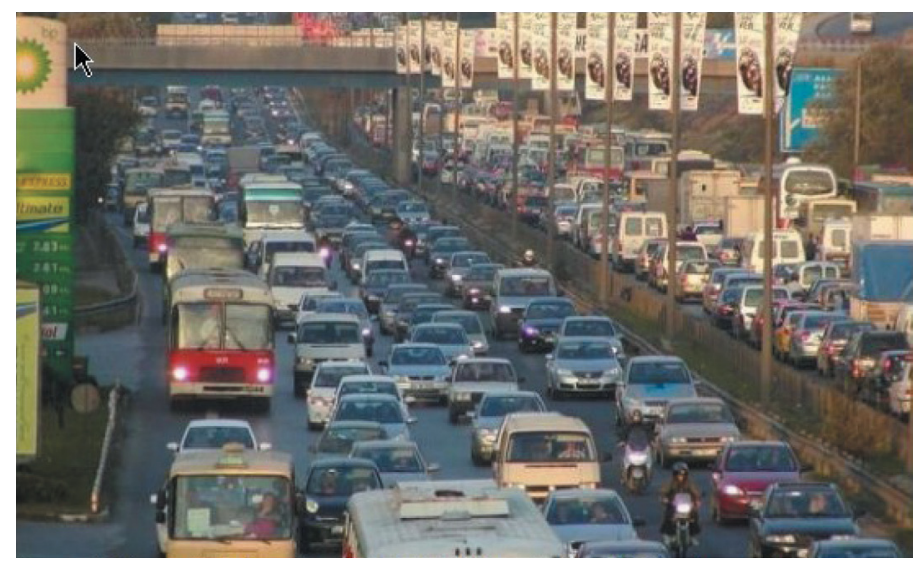

Figure 6: D-100 corridor before BRT implementation.

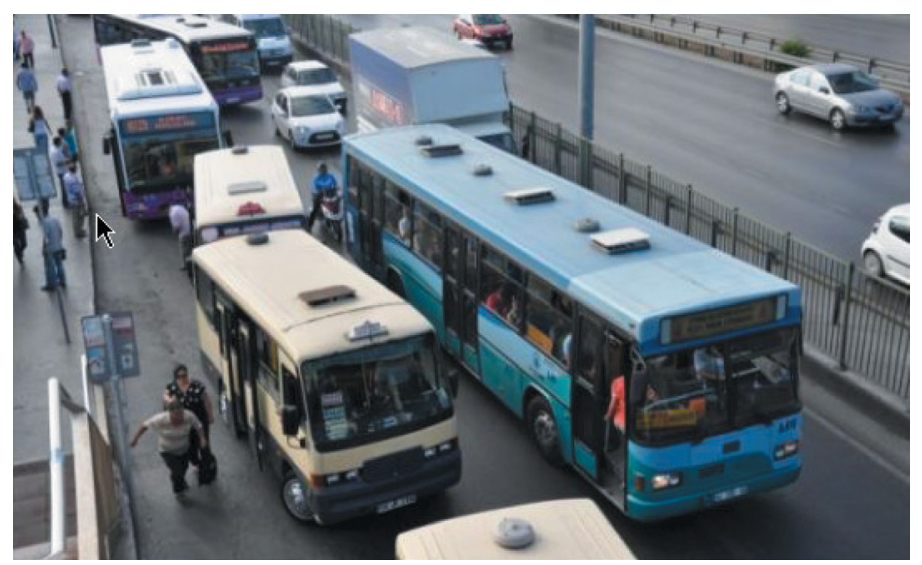

Figure 7: Conventional buses and minibuses. 


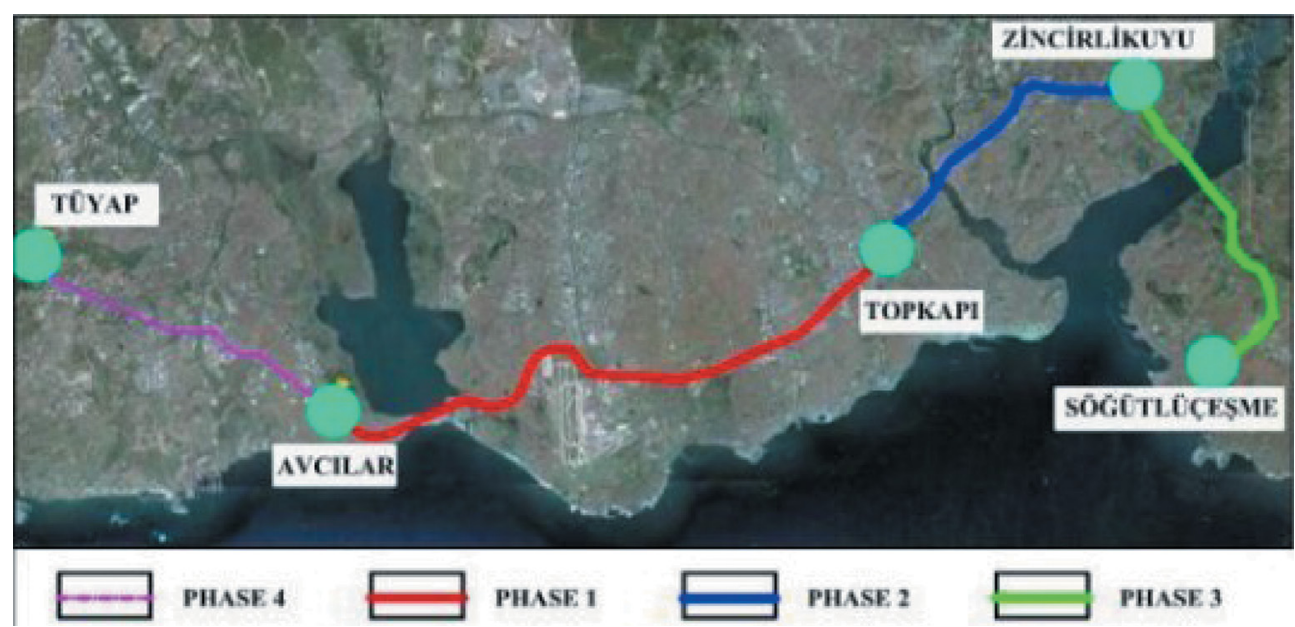

Figure 8: Phases of BRT in Istanbul [6].

6 BRT CORRIDOR IN ISTANBUL

The first BRT corridor in Istanbul started operation in September 2007 between Avcrlar and Topkap1 with $18.2 \mathrm{~km}$ route length. The first phase became very successful and fulfilled the objectives by reducing travel times, reducing private car usage by attracting people with highquality and fast service via operating high-technology buses and eliminating low-tech conventional transport modes; it was also estimated that BRT reduced $\mathrm{CO}_{2}$ emissions (Fig. 8).

After high ridership rates in the first phase, one year later Phase II started operation in September 2008 with $11.8 \mathrm{~km}$ route length between Topkapı and Zincirlikuyu. Phase III started operation in September 2009 with $11.5 \mathrm{~km}$ route length. This phase connects two continents via Bosporus Bridge, which makes it the first and only intercontinental BRT line in the world. More importantly, it gives the system an important advantage since it provides a high-quality and significantly faster public transport service in one of the most congested bottlenecks of the city. Phase IV was opened in July 2012 between Avcrlar and Tüyap Fair and Convention Center with $9.7 \mathrm{~km}$ route length [8].

BRT in Istanbul is a shining star in the world of BRT; it consists of 44 stations with $52 \mathrm{~km}$ route length. Metrobüs carries 872,527 passengers/weekday. The system has fully segregated running ways and does not intersect with the general traffic except in the Bosporus Bridge section; this makes Metrobüs the fastest BRT operation in the world with a commercial speed of $35 \mathrm{~km} / \mathrm{h}$ [9].

\section{CHARACTERISTICS OF METROBÜS}

\subsection{Running ways}

Metrobüs operates on D-100 and O-1 highways with fully segregated median bus ways (except for the Bosporus Bridge section) with $52 \mathrm{~km}$ route length. There is one lane in each direction and it is segregated from the general traffic with physical barriers and from other BRT lane with road markings. Since the doors of the vehicles are located on the right side, buses run on the left side of the traffic counter to the general traffic flow [10] (Fig. 9). 


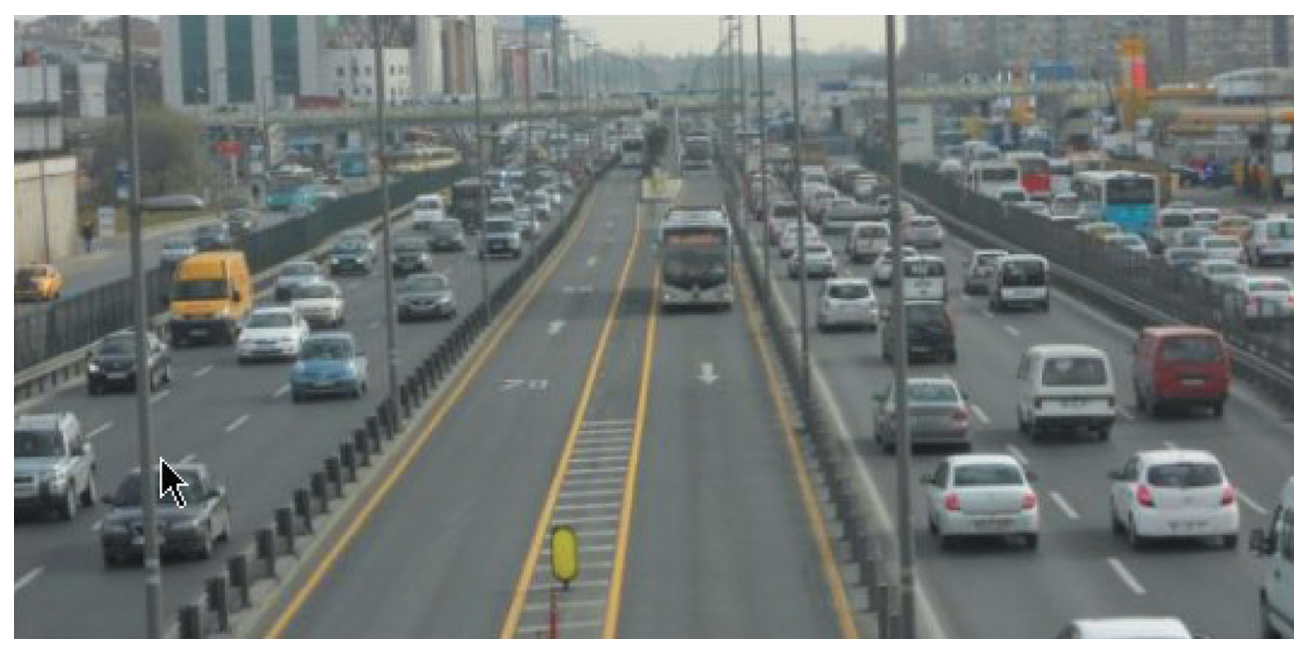

Figure 9: Fully segregated median running ways.

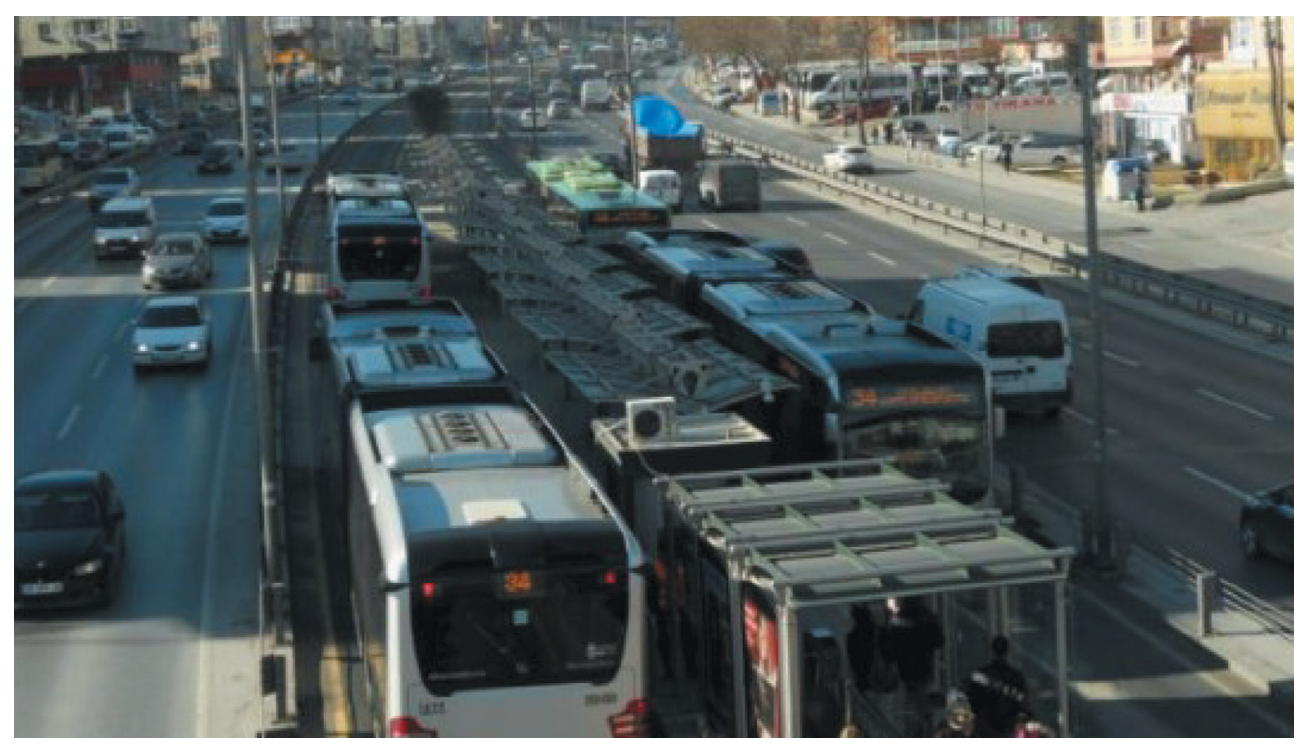

Figure 10: Median stations.

\subsection{Stations}

There are 44 stations in the corridor. This corresponds to an average station spacing of 1.2 $\mathrm{km}$ (average distance between stations), which is quite high and appropriate for a rapid transit system. Since running ways are limited with total of two lanes, there is no passing lane at stations. Platform length is $60 \mathrm{~m}$, which allows two 26-m-long buses or three 18-m-long buses to serve at the same time at stations. Since BRT corridor is located in the middle of the highway, access to the platform is provided via under- or overpasses [10] (Fig. 10). 


\subsection{Vehicles}

High-capacity and high-technology buses are used in the system. In order to provide high capacity, articulated and bi-articulated buses are used. Vehicles meet Euro III and Euro IV emission standards [10].

\subsection{Fare collection}

Fare collection is off-board in the system. Passengers use their smart cards while accessing the platforms. This significantly reduces time during boarding [10] (Fig. 11).

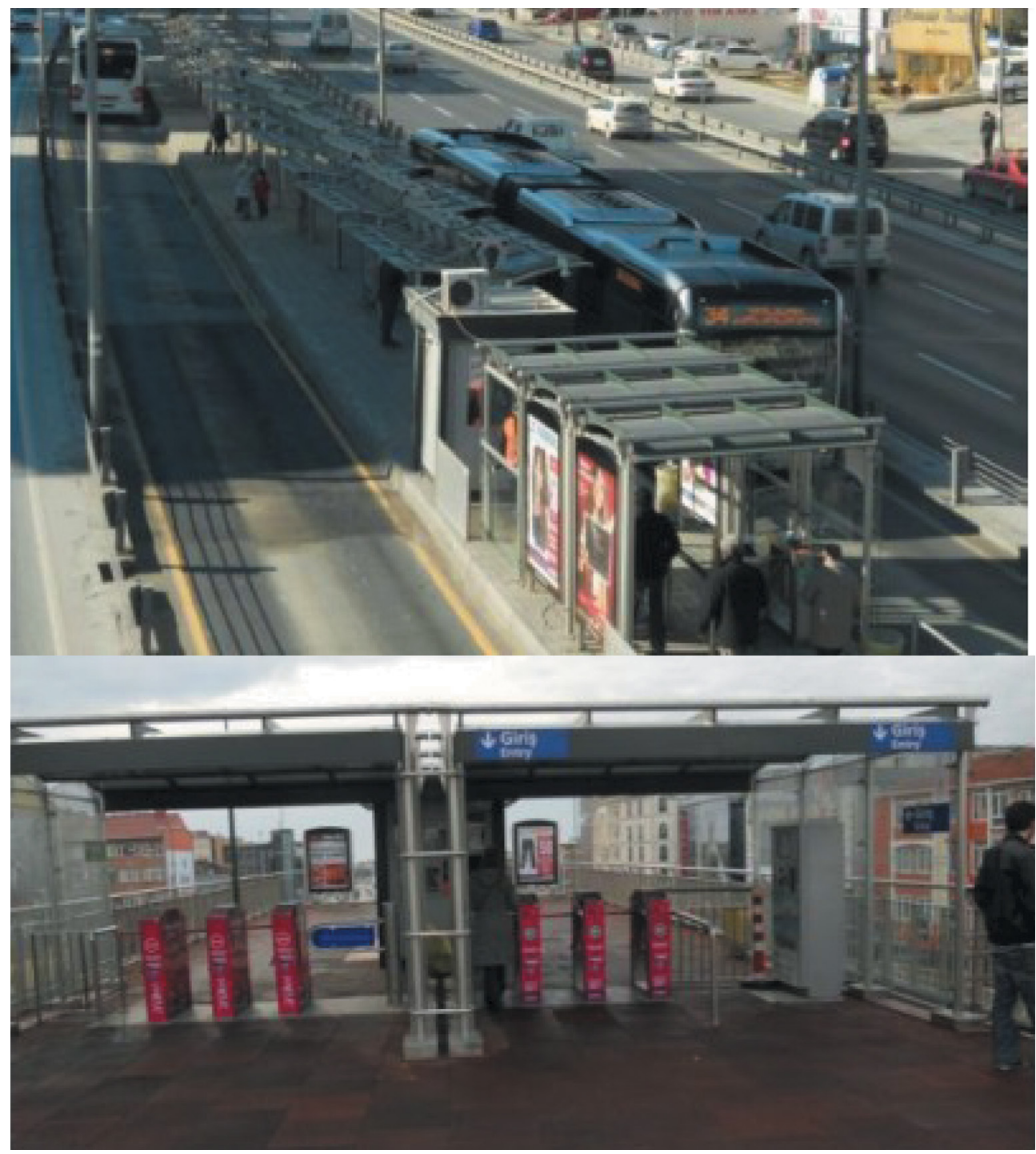

Figure 11: Off-board fare collection. 
According to the İstanbul Electricity Tramway and Tunnel General Directorate, the operating authority, the first three phases provided 52 min time savings/day/person. Some bus and minibus routes were removed from the BRT corridor after Metrobüs. This resulted in 209 less buses and 1,296 less minibuses on roads. After BRT, 242 tonnes less fuel was used in public transport daily. BRT system has positive impacts on the environment as well, with 80,000 vehicles being removed from the road daily, resulting in 623 tonnes less $\mathrm{CO}_{2}$ and 282 tonnes less NO that causes smog, acid rains, global warming and many other health complications [11].

BRT system also has reduced accident rates on the corridor. Fewer vehicles on the D-100 highway means less congestion and less accidents. This means BRT has positive effects on economy in terms of both vehicle industry and health sector [11].

\section{CONCLUSION}

Istanbul Metrobüs appears to be a successful rapid transit system that carries high numbers of passengers. The operation characteristics also indicate that the system provides very high quality service. Istanbul BRT is reported to have had positive effects on the environment as well; after Metrobüs in Istanbul many of the conventional bus and minibus lanes were either removed or reorganized as a feeder service. It is reported that 623 tonnes of $\mathrm{CO}_{2}, 283$ tonnes NO $x$ and 25 tonnes of hydrocarbon were reduced daily. BRT buses travel 160,000 km every day and use 70 tonnes of fuel daily. By introducing BRT system, 242 tonnes of fuel has been saved from public transport [11], [12] and [13].

\section{REFERENCES}

[1] http://istanbul-tourist-information.com/wissenswertes-uber-istanbul/wissenswertesuber-istanbul (accessed 12 February 2016).

[2] Turkish Statistical Institute, Demographic Data, 2016.

[3] Istanbul transportation Master Plan, 2011.

[4] Grava, Sigurd, Urban Transportation Systems, 2002.

[5] Black, Alan, Urban Mass Transportation Planning, The History of Urban Transit, McGraw-Hill, 1995.

[6] Levinson, H.S., et al. Bus rapid transit: an overview. Journal of Public Transport, 5(2), pp. 1-30, 2002. DOI: 10.5038/2375-0901.5.2.1.

[7] Wright, L. \& Hook, R., Bus Rapid Transit Planning Guide, 2007, Institute for Transportation and Development Policy: New York. 3rd edition, June 2007.

[8] Pelin Alpkökin and Murat Ergün, İstanbul Metrobüs: First Intercontinental Bus Rapid Transit. Journal of Transport Geography, September 2012.

[9] http://www.worldbrt.net/en/cities/istanbul.aspx.

[10] Yüce, Elif Can, An assessment of the planning and operational performance of the Bus Rapid Transit in Istanbul, 2013.

[11] Kahveci, Mümin, IETT Presentation, 5th Transportation Symposium and Fair, Istanbul, 2012.

[12] Sutcliffe, E.B. \& Cengiz, E.C., The Bus Rapid Transit System in Istanbul: A Success Story or Flawed Planning Decision? Transport Reviews, June 2015. http://www.tandfonline. com/doi/full/10.1080/01441647.2015.1059381

[13] http://www.nufusu.com/il/istanbul-nufusu. 